ISSN Print: 2151-7517, ISSN Online: 2151-7525, doi:10.5251/abjna.2011.2.4.603.609

(C) 2011, ScienceHu $\beta$, http://www.scihub.org/ABJNA

\title{
Soil nutrient supplementation on growth and biomass production of Roselle under tropical conditions
}

\author{
N. Anyinkeng and Afui M. Mih \\ Department of Plant and Animal Sciences, University of Buea PO Box 63, Buea, \\ Cameroon
}

\begin{abstract}
Pot experiments were carried out to evaluate the effects of supplementing soil nutrients with different levels each of NPK (20:10:10) and poultry manure on the growth and biomass production of Roselle (Hibiscus sabdariffa L.). Soil supplemented with 20 ton ha ${ }^{-1}$ poultry manure significantly $(\rho=0.05)$ increased growth, partitioning over $80 \%$ of dry weight to shoots. Treated plants flowered at 10 weeks after sowing. Anthocyanin was more concentrated in the leaves of plants treated with chemical fertilizer than in manure-treated and control plants, but the trend reversed at 18 weeks. It was concluded that 20 ton ha poultry manure significantly increased growth, biomass, and economic yield of Roselle.
\end{abstract} \section{INTRODUCTION}

Keywords: Nutrient supplementation, yield

The vegetable Roselle, Hibiscus sabdariffa var sabdariffa $L$ is grown as a leafy vegetable and juice extracted from the calyces is also consumed in Cameroon (Schippers, 2000). There is need for production to be increased to meet demand. Roselle prefers a well drained humus rich fertile soil in full sun, though it adapts to a variety of soils (Pellizer, 2004). Adapting its production in southwestern Cameroon requires knowledge of its soil nutrient requirements. This project was undertaken to determine effects of soil amendment with organic and synthetic fertilizer on growth and biomass of Roselle.

\section{MATERIALS AND METHODS}

The work was done at the University of Buea, Cameroon in 2008. Top soil, volcanic in nature, was collected from fallow land and air-dried under shade for two weeks. The soil was used as a base from which potting mixes were developed (Table 1). Each was thoroughly mixed to ensure homogeneity. Representative samples of each mix was analyzed for routine soil nutrients in the Soil Laboratory of the International Institute of Tropical Agriculture (IITA), Nkolbeson, Yaounde.

Table 1. Composition of soil nutrient amendments

\begin{tabular}{|l|l|}
\hline Treatment & \multicolumn{1}{|c|}{ Composition $^{\text {a }}$} \\
\hline T1 & $\begin{array}{l}\text { Air-dried soil only, no amendment with } \\
\text { fertilizer }\end{array}$ \\
\hline T2 & Air-dried soil mixed with $60 \mathrm{~kg} \cdot \mathrm{ha}^{-1}$ of NPK \\
\hline T3 & $\begin{array}{l}\text { Air-dried soil mixed with } 120 \mathrm{~kg} \cdot \mathrm{ha}^{-1} \text { of } \\
\text { NPK }\end{array}$ \\
\hline T4 & $\begin{array}{l}\text { Air-dried soil mixed with } 180 \mathrm{~kg} \cdot \mathrm{ha}^{-1} \text { of } \\
\text { NPK }\end{array}$ \\
\hline T5 & $\begin{array}{l}\text { Air-dried soil mixed with } 10 \mathrm{Mt} \cdot \mathrm{ha}^{-1} \text { of } \\
\text { poultry manure }\end{array}$ \\
\hline T6 & $\begin{array}{l}\text { Air-dried soil mixed with } 20 \mathrm{Mt} \cdot \mathrm{ha}^{-1} \text { of } \\
\text { poultry manure }\end{array}$ \\
\hline a 1 ha $=2 \times 10^{6} \mathrm{~kg}$ soil.
\end{tabular}

b Moisture content of well decomposed poultry manure was $32.4 \%(\mathrm{w} / \mathrm{w})$.
Establishment and Management of Test Plants: Fifty plastic pots $(14 \mathrm{~cm}$ diameter) were filled with each mix to a level of about $2 \mathrm{~cm}$ below the brim of the pot. The pots were arranged in a completely randomized design with five replicates. Each pot was sown with four Roselle seeds. One week after germination, plants were thinned to one per pot. The pots were watered regularly (twice a week throughout the entire study period), and weed control was done manually.

Data collection: Growth parameters (Table 2) were measured biweekly. At 14 weeks after sowing five plants per treatment were each carefully removed from the pot and the soil adhering to the roots removed by washing under water from a slow running tap. Plants were separated into the roots, stems (including branches) and leaves, and each placed in an envelope and oven-dried at $60^{\circ} \mathrm{C}$ for $72 \mathrm{hrs}$. Dry weight of roots (RDW), stems (SDW) and leaves (LDW) were recorded. At anthesis (18 weeks after sowing), five plants were randomly selected from each treatment and number of flower buds counted. Five flower buds were harvested from five plants per treatment and for each flower bud the diameter and the length of each fresh calyx were measured. The buds were oven dried at $60^{\circ} \mathrm{C}$ for $72 \mathrm{hrs}$ and dry weights recorded.

Table 2. Growth parameters of Hibiscus sabdariffa measured.

\begin{tabular}{|l|l|}
\hline Parameter & Method \\
\hline Plant height (PH), cm & $\begin{array}{l}\text { From the soil collar to the tip } \\
\text { of the plant }\end{array}$ \\
\hline $\begin{array}{l}\text { Stem diameter (SD), } \\
\mathrm{mm}\end{array}$ & At $10 \mathrm{~cm}$ from the soil collar \\
\hline $\begin{array}{l}\text { Number of leaves per } \\
\text { plant (NLPP) }\end{array}$ & $\begin{array}{l}\text { Fully opened leaves from two } \\
\text { weeks after }\end{array}$ \\
\hline $\begin{array}{l}\text { Number of branches } \\
\text { per plant (NBBP) }\end{array}$ & Four weeks after sowing. \\
\hline Time to flowering & Weeks after planting. \\
\hline
\end{tabular}

The relative anthocyanin concentration in leaves and calyces was determined in methanolic extracts 
by the method of Gitelson et al. (2001) with slight modification. The material to be extracted was homogenized in methanol containing $1 \mathrm{~g} \cdot \mathrm{mL}^{-1}$ of $\mathrm{Na}_{2} \mathrm{CO}_{3}$. The extract was centrifuged at $3000 \mathrm{~g}$ for $15 \mathrm{~min}$ and the supernatant collected. Five 2-fold dilutions of each extract were made with distilled water and the absorbance measured at $550 \mathrm{~nm}$ using a spectrophotometer (Du Series 500, Beckman, UK). The blank in each case was the corresponding dilution of methanol in water.

Data Analysis: The data were subjected to a OneWay Analysis of Variance using Minitab version13. Means were separated using Duncan's New Multiple Range Test $(\rho=0.05)$.

\section{RESULTS AND DISCUSSION}

There were no significant differences in plant height at two weeks after sowing but plants grown on manure-supplemented media were taller than for other treatments by eight weeks after sowing (Fig. 1). The results were similar for stem diameter (Fig.

Table 3. Nutrient status of soil amended with synthetic fertilizer or manure.

\begin{tabular}{|c|c|c|c|c|c|c|c|c|}
\hline Amendment ${ }^{a}$ & $\mathrm{pH}$ & $\mathrm{Ca}$ & $\begin{array}{l}\mathrm{Mg} \\
\mathrm{cmol}(+) \cdot \mathrm{kg}^{-1}\end{array}$ & K & $\begin{array}{l}\text { Bray P } \\
(\mathrm{mg} / \mathrm{kg})\end{array}$ & $\begin{array}{l}\text { Organic } \\
\text { carbon } \\
(\%)\end{array}$ & $\begin{array}{l}\text { Total } \\
N \\
(\%)\end{array}$ & $\mathrm{C} / \mathrm{N}$ \\
\hline T1 & 5.87 & 7.98 & 3.1 & 5.5 & 23.21 & 2.09 & 0.195 & 10.69 \\
\hline T2 & 5.79 & 8.04 & 2.7 & 4.82 & 23.66 & 2.01 & 0.196 & 10.24 \\
\hline T3 & 5.68 & 7.12 & 2.67 & 4.85 & 21.33 & 2.16 & 0.214 & 10.08 \\
\hline T4 & 5.9 & 11.51 & 5.15 & 4.83 & 85.61 & 2.99 & 0.267 & 11.2 \\
\hline T5 & 6.09 & 20.28 & 7.62 & 6.34 & 422.01 & 4.77 & 0.387 & 12.32 \\
\hline T6 & 6.39 & 23.75 & 10.24 & 8.65 & 704.44 & 5.64 & 0.513 & 10.99 \\
\hline
\end{tabular}

${ }^{\mathrm{a}}$ T1= Control, T2 = NPK $60 \mathrm{~kg} \mathrm{ha}^{-1}, \mathrm{~T} 3=$ NPK $120 \mathrm{~kg} \mathrm{ha}^{-1}, \mathrm{~T} 4=$ NPK $180 \mathrm{~kg} \mathrm{ha}^{-1}, \mathrm{~T} 5=$ poultry manure 20 ton ha ${ }^{-1}, \mathrm{~T} 6=$ poultry manure 40 ton $\mathrm{ha}^{-1}$.

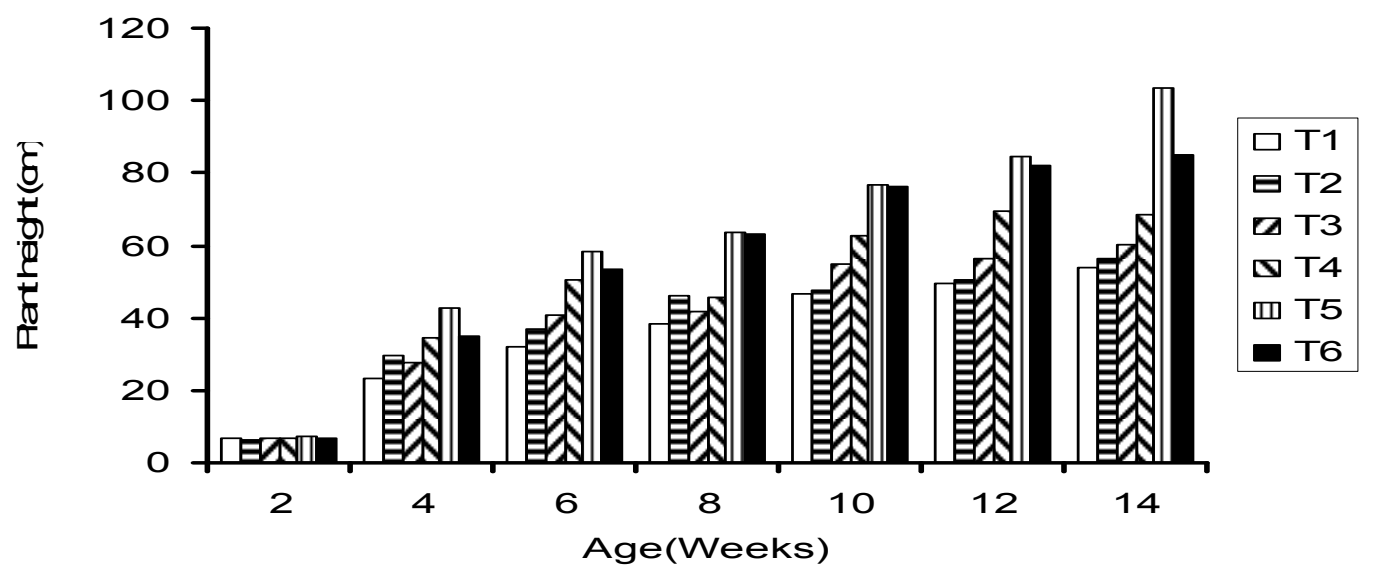

Fig1. Plant height of Hibiscus sabdariffa plants grown with nutrient amendment: T1= Control, $\mathrm{T2}=\mathrm{NPK} 60 \mathrm{~kg} \cdot \mathrm{ha}$ ${ }^{1}, \mathrm{~T} 3=\mathrm{NPK} 120 \mathrm{~kg} \cdot \mathrm{ha}^{-1}, \mathrm{~T} 4=\mathrm{NPK} 180 \mathrm{~kg} \cdot \mathrm{ha}^{-1}, \mathrm{~T}^{-1}=$ poultry manure, $20 \mathrm{Mt} \cdot \mathrm{ha}^{-1}, \mathrm{~T}^{-1}=$ poultry manure, $40 \mathrm{Mt} \cdot \mathrm{ha}^{-1}$. 


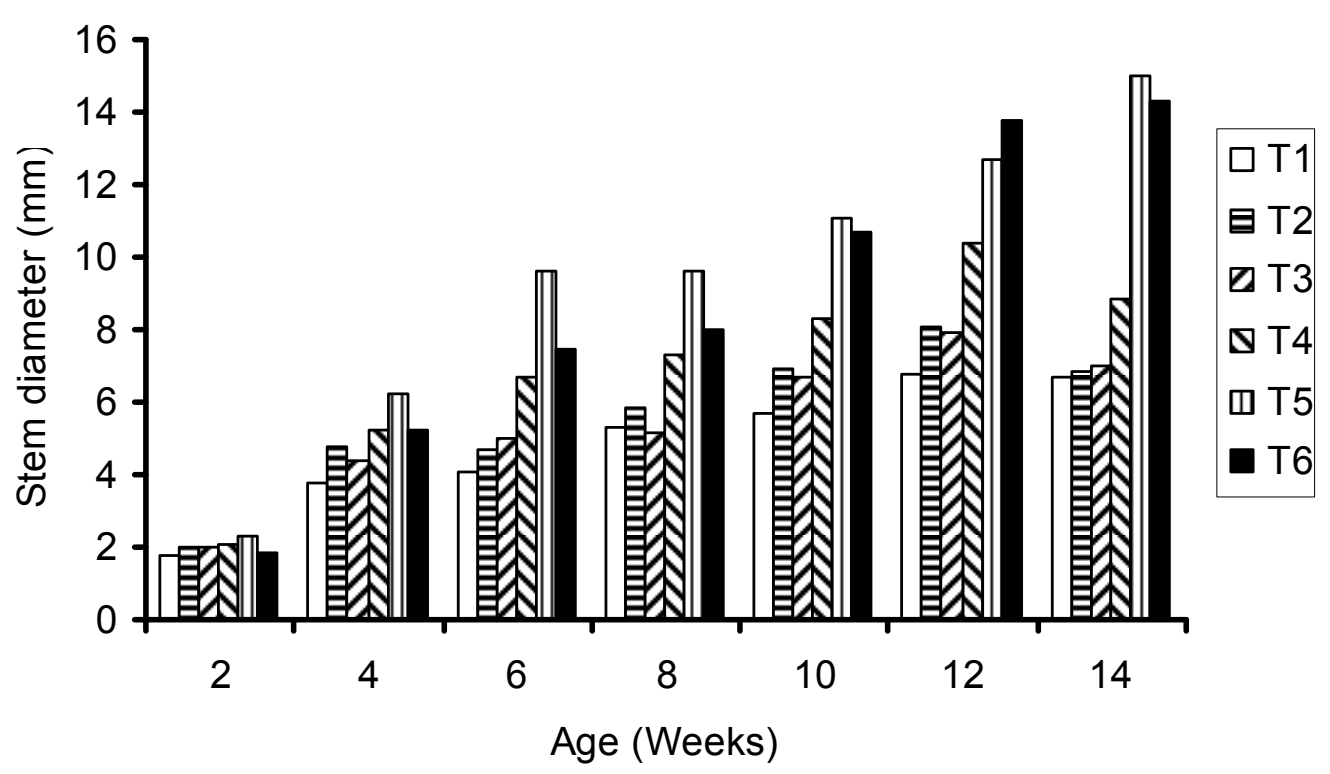

Fig 2. Stem diameter of Hibiscus sabdariffa plants grown with nutrient amendment: T1= Control, T2 = NPK 60 $\mathrm{kg} \cdot \mathrm{ha}^{-1}, \mathrm{~T} 3=\mathrm{NPK} 120 \mathrm{~kg} \cdot \mathrm{ha}^{-1}, \mathrm{~T} 4=\mathrm{NPK} 180 \mathrm{~kg} \cdot \mathrm{ha}^{-1}, \mathrm{~T} 5=$ poultry manure, $20 \mathrm{Mt} \cdot \mathrm{ha}^{-1}, \mathrm{~T} 6=$ poultry manure, 40 Mt.ha .

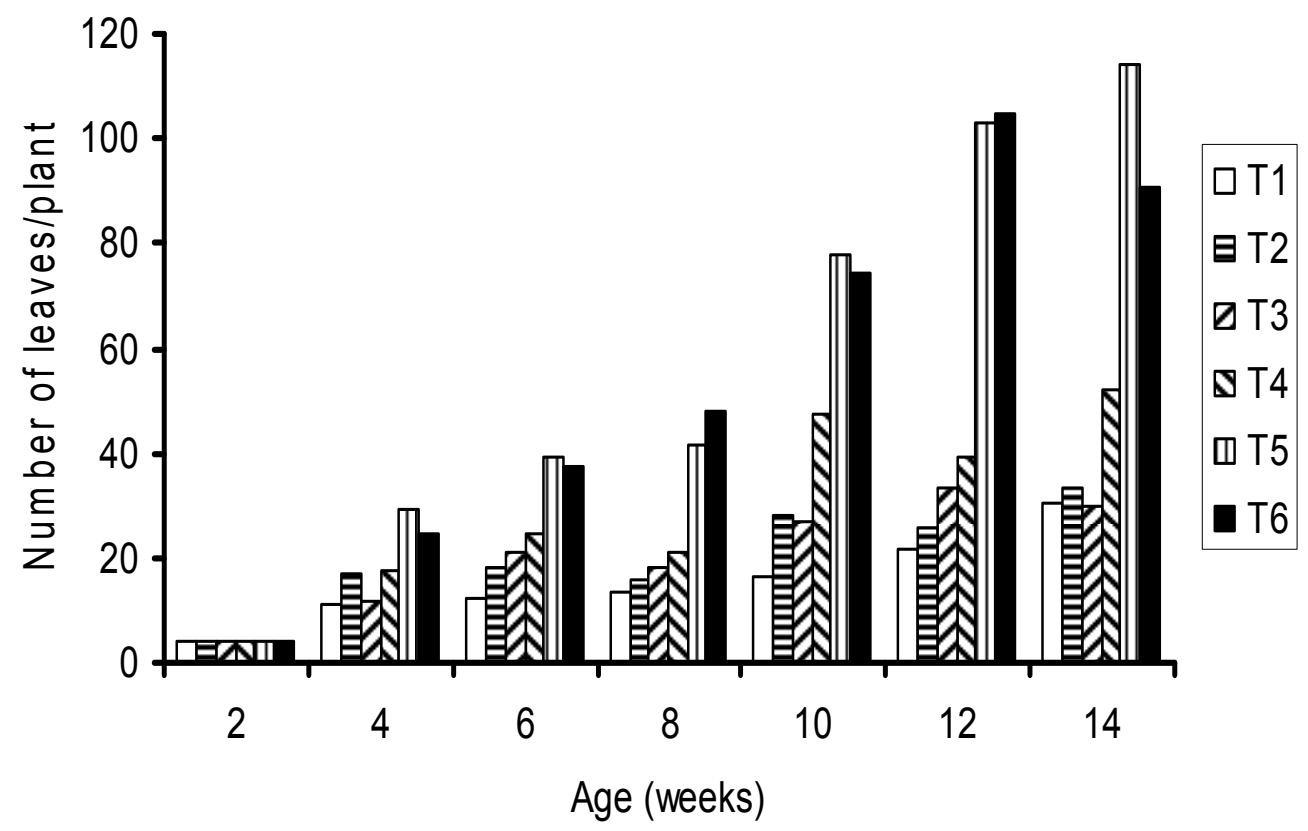

Fig 3 Number of leaves per plant of Hibiscus sabdariffa plants grown with nutrient amendment: T1 = Control, T2 $=$ NPK $60 \mathrm{~kg} \cdot \mathrm{ha}^{-1}{ }_{-1}{ }_{-1} 3=\mathrm{NPK} 120 \mathrm{~kg} \cdot \mathrm{ha}^{-1}, \mathrm{~T} 4=\mathrm{NPK} 180 \mathrm{~kg} \cdot \mathrm{ha}^{-1}, \mathrm{~T} 5=$ poultry manure, $20 \mathrm{Mt} \cdot \mathrm{ha}^{-1}, \mathrm{~T} 6=$ poultry manure, $40 \mathrm{Mt} \cdot \mathrm{ha}$ 


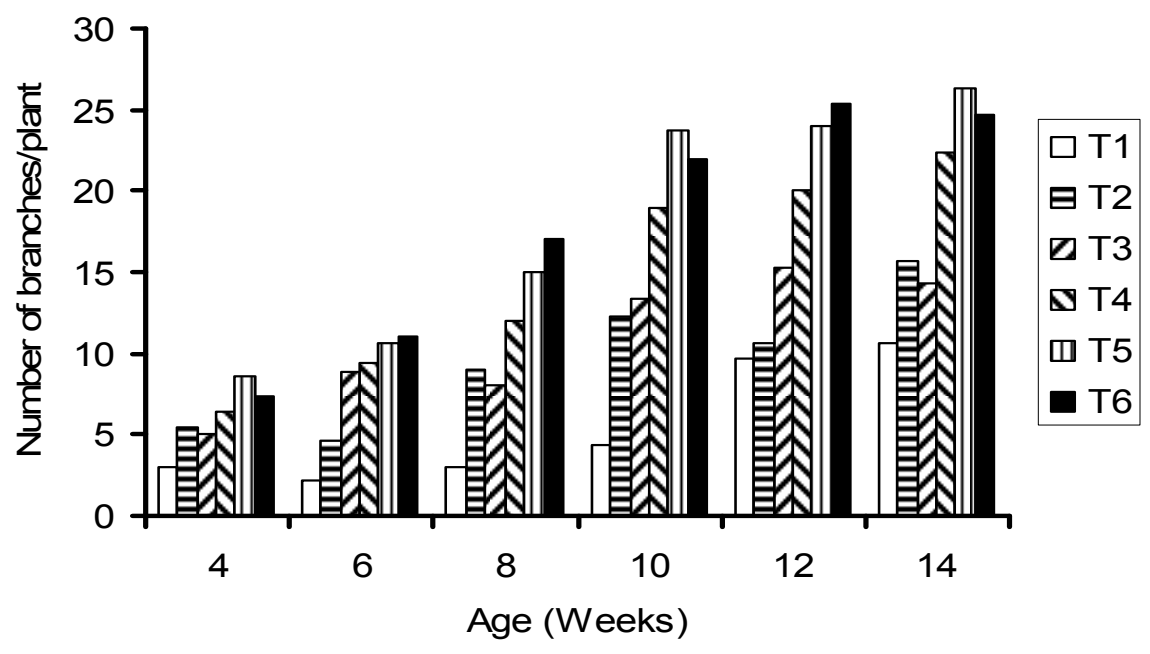

Fig 4. Number of branches per plant of Hibiscus sabdariffa for plants grown with nutrient amendment: T1 = Control, T2 = NPK $60 \mathrm{~kg} \cdot \mathrm{ha}^{-1}{ }^{-1}, \mathrm{~T} 3=\mathrm{NPK} 120 \mathrm{~kg} \cdot \mathrm{ha}^{-1}, \mathrm{~T} 4=\mathrm{NPK} 180 \mathrm{~kg} \cdot \mathrm{ha}^{-1}, \mathrm{~T}^{-1}=$ poultry manure, $20 \mathrm{Mt} \cdot \mathrm{ha}^{-1}, \mathrm{~T}^{-1}=$
poultry manure, $40 \mathrm{Mt} \cdot \mathrm{ha}^{-}$

Plants supplemented with $20 \mathrm{Mt} \cdot \mathrm{ha}^{-1}$ of poultry manure accumulated more biomass over the 14 week growth period (Fig. 5). These plants partitioned above $80 \%$ of biomass to the shoot at 14 weeks after sowing (Fig. 5). At this stage manure treated plants had more leaves and branches and were taller and more robust than for other treatments. This luxuriant vegetative growth is desirable for a leafy vegetable (Schippers, 2000).

When grown for juice, Rossel flowers become economically important. Plants on manuresupplemented media produced flower buds that were larger than those of the plants receiving synthetic fertilizer and the control (Table 4). Plants on manure - supplemented media flowered earlier than for the other treatments. Plants in media with manure flowered early because the vigorous and rapid growth of plants caused tap roots to become restricted by the bonsai effect. Similar effects have been recorded for Gossypium spp (Ben-Porath and Baker, 1990).
Plants in soil supplemented with N-P-K fertilizer had higher anthocyanin concentration in leaves than those on manure - supplemented media (Fig 6). The trend was reversed when anthocyanin was estimated in the calyces (Fig 7). The anthocyanin concentration in leaves was generally lower than in calyces. Anthocyanin is responsible for the wine color in the drink derived from the Roselle. The high concentration of this pigment in the calyces of plants grown on manure-supplemented media is economically important in that larger quantities of the drink can be produced by dilution, while still maintaining color intensity at acceptable levels. The high dilution also reduces the undesirable background sour taste in the crude juice. The reduced levels of anthocyanin in calyces of plants grown on fertilizer amended media could be attributed to competitive partitioning of synthesis to the leaves (Gitelson et al. 2001). 


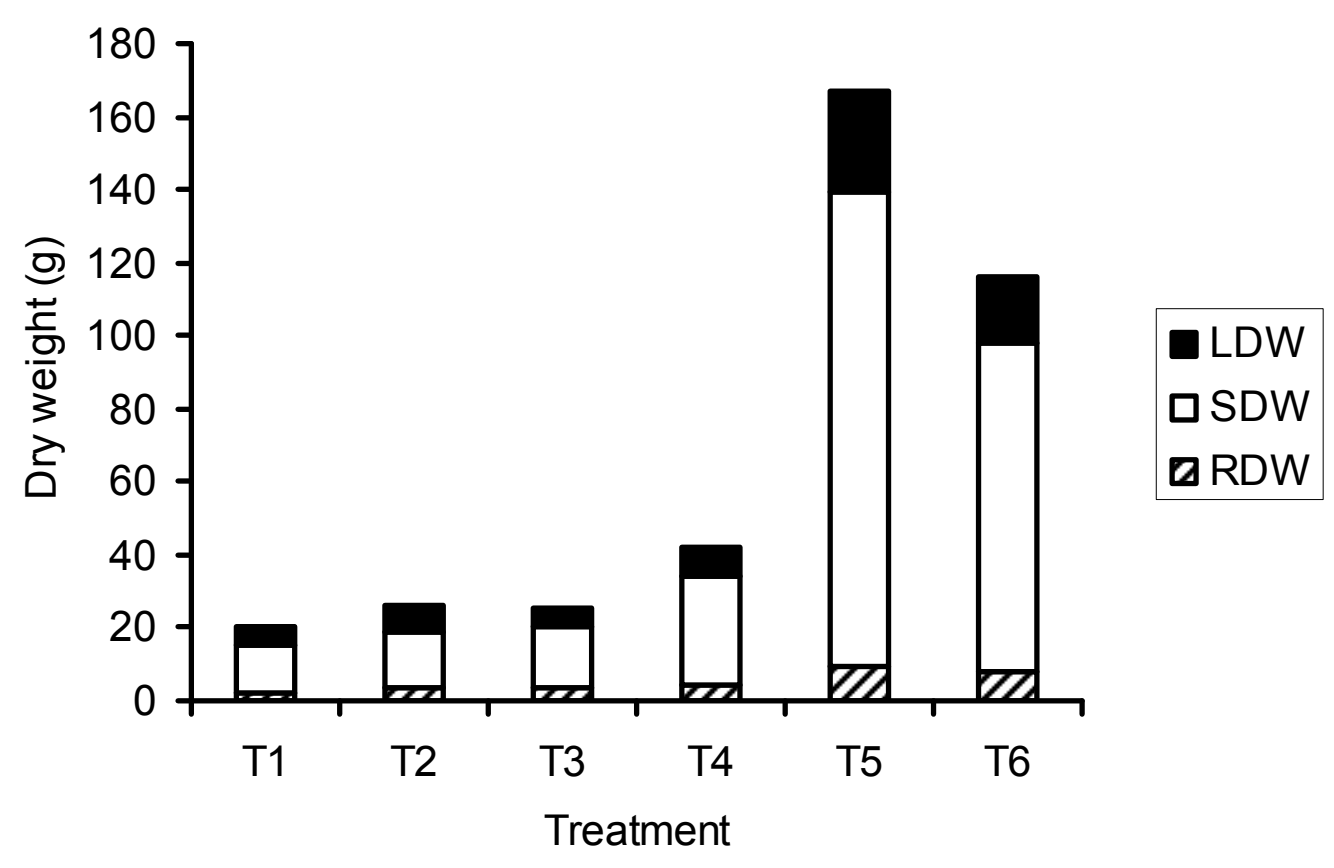

A

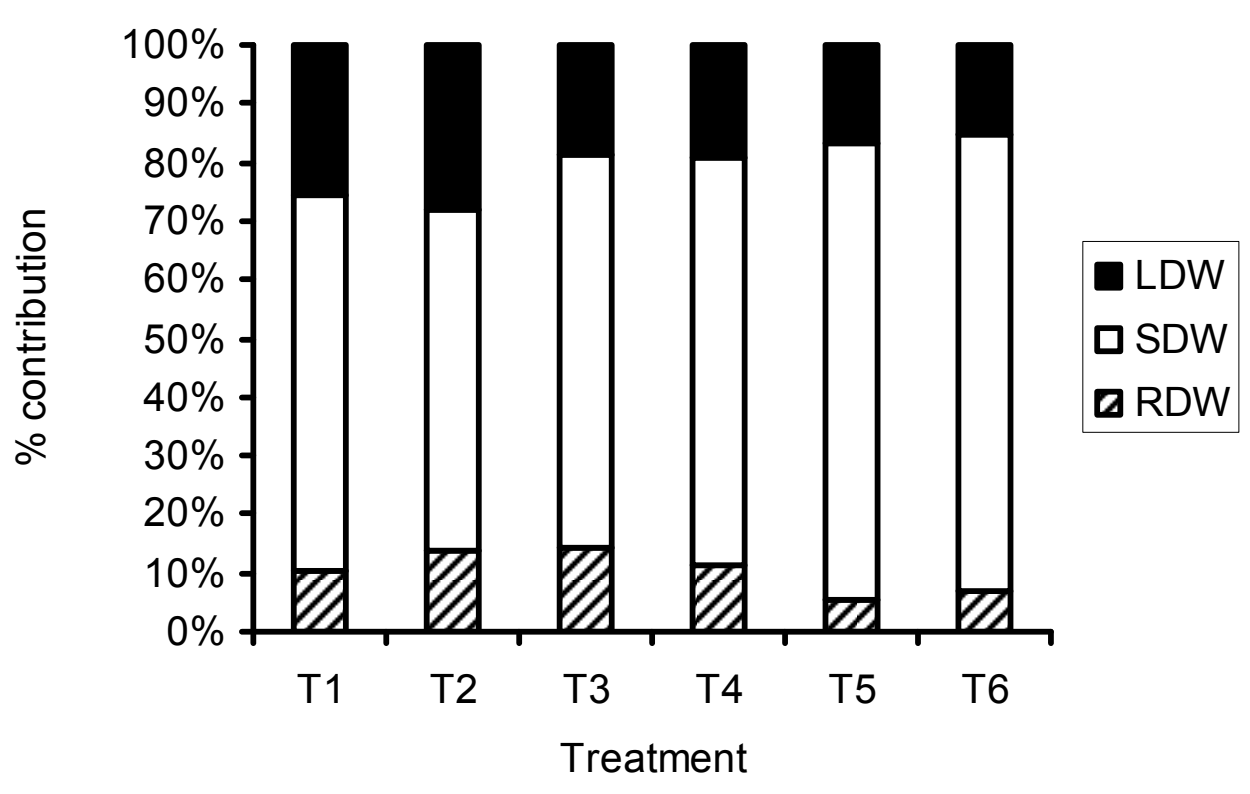

B

Fig 5. Dry matter distribution at 14 weeks after sowing of Hibiscus sabdariffa for plants provided various amendments, A) dry matter of roots, stem and leaves per plant. B) proportion of total dry matter of root, stem and leaves per plant: T1 $=$ Control, T2 $=$ NPK $60 \mathrm{~kg} \cdot \mathrm{ha}^{-1}, \mathrm{~T}_{3}=\mathrm{NPK} 120 \mathrm{~kg} \cdot \mathrm{ha}^{-1}, \mathrm{~T} 4=\mathrm{NPK} 180 \mathrm{~kg} \cdot \mathrm{ha}^{-1}, \mathrm{~T}^{\mathrm{T}}=$ poultry manure, $20 \mathrm{Mt} \cdot \mathrm{ha}^{-1}, \mathrm{~T} 6=$ poultry manure, $40 \mathrm{Mt} \cdot \mathrm{ha}^{-1}$. RDW=Root dry weight, SDW=Stem dry weight, LDW=Leaf dry weight 
Agric. Biol. J. N. Am., 2011, 2(4): 603-609

Table 4. Floral characters at maturity of Hibiscus sabdariffa provided various amendments.

\begin{tabular}{|c|c|c|c|c|c|c|c|}
\hline \multirow[t]{2}{*}{ Treatment } & \multicolumn{4}{|c|}{ Parameter } & & & \\
\hline & $\begin{array}{c}\text { Flower } \\
\text { buds } \\
\text { (no/plant) }\end{array}$ & $\begin{array}{l}\text { Diameter of } \\
\text { fresh flower } \\
\text { bud }(\mathrm{mm})\end{array}$ & $\begin{array}{l}\text { Fresh weight of } \\
\text { flower bud }(\mathrm{g})\end{array}$ & $\begin{array}{l}\text { Dry weight of } \\
\text { flower bud }(\mathrm{g})\end{array}$ & $\begin{array}{l}\text { Length of calyx } \\
(\mathrm{cm})\end{array}$ & $\begin{array}{c}\text { Calyx dry } \\
\text { weight } \\
\text { (g) }\end{array}$ & $\begin{array}{l}\text { Time to } \\
\text { flowering } \\
\text { (weeks) }\end{array}$ \\
\hline T1 & $31 a \pm 12$ & $20.06 a \pm 1.43$ & $2.76 a \pm 0.94$ & $0.36 a \pm 0.05$ & $2.50 a \pm 0.45$ & $0.16 a \pm 0.09$ & 16 \\
\hline T2 & $42 a \pm 1.0$ & $21.9 b \pm 2.31$ & $3.48 a \pm 0.54$ & $0.44 a \pm 0.05$ & $2.66 a b \pm 0.17$ & $0.22 a \pm 0.04$ & 14 \\
\hline T3 & $47 a \pm 17$ & $23.3 a b \pm 5.19$ & $3.96 a \pm 2.23$ & $0.64 b \pm 0.21$ & $2.58 a \pm 0.31$ & $0.30 a \pm 0.10$ & 14 \\
\hline $\mathrm{T} 4$ & $55 a \pm 12$ & $26.68 \mathrm{~b} \pm 4.32$ & $6.16 b \pm 1.04$ & $0.72 b c \pm 0.13$ & $3.06 b \pm 0.25$ & $0.28 b \pm 0.08$ & 12 \\
\hline T5 & $93 c \pm 18$ & $32.4 c \pm 2.77$ & $7.32 b c \pm .48$ & $1.10 c \pm 0.18$ & $3.18 b c \pm 0.36$ & $0.28 b \pm 0.11$ & 10 \\
\hline T6 & $82 b \pm 38$ & $33 c \pm 0.87$ & $7.32 b c \pm .48$ & $1.38 c \pm 0.13$ & $3.54 b \pm 0.05$ & $0.44 c \pm 0.44$ & 10 \\
\hline
\end{tabular}

Values along a row having the same letter are not significantly different at $\rho=0.05$ (DNMRT).

T1= Control, T2 = NPK $60 \mathrm{~kg} \mathrm{ha}^{-1}$, T3 = NPK $120 \mathrm{~kg} \mathrm{ha}^{-1}, \mathrm{~T} 4=\mathrm{NPK} 180 \mathrm{~kg} \mathrm{ha}^{-1}$, T5 = poultry manure, 20 ton ha ${ }^{-1}, \mathrm{~T}^{2}=$ poultry manure, 40 ton ha $^{-1}$

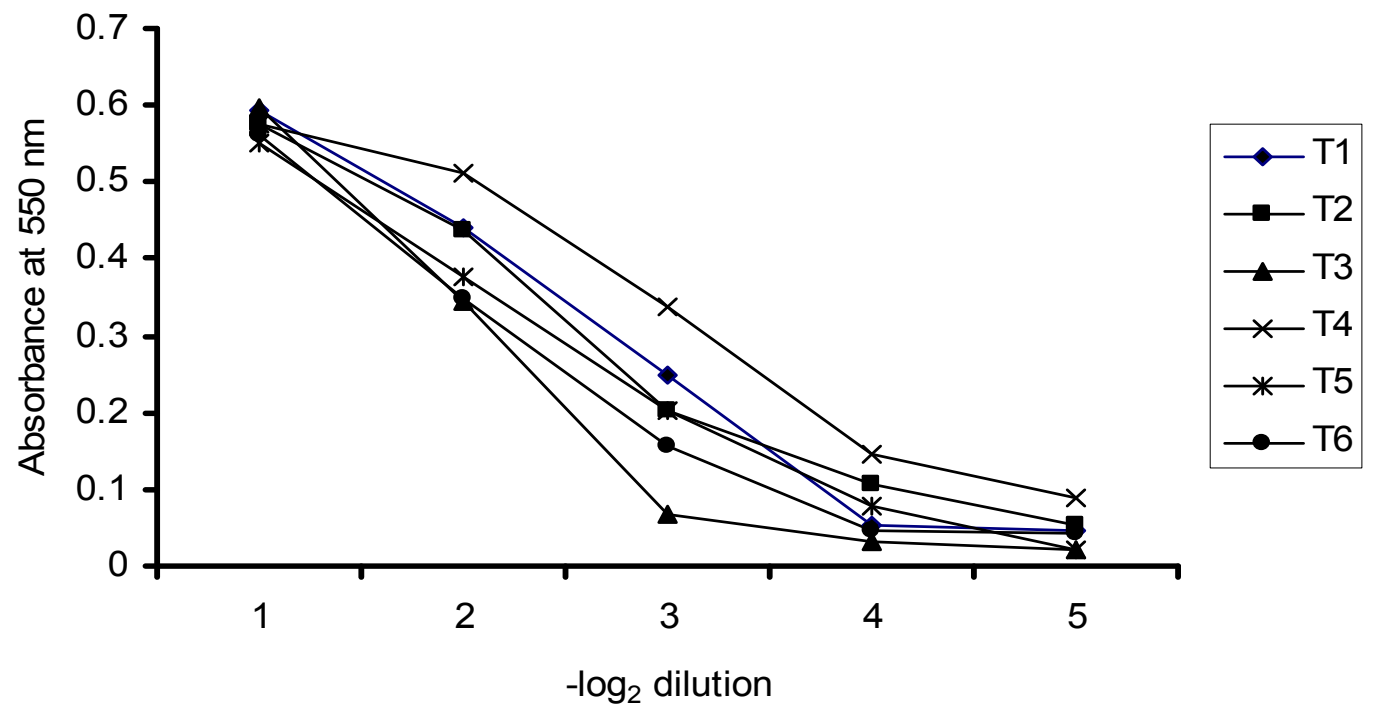

Fig 6. Optical density of water-diluted methanolic extracts of leaves of Hibiscus sabdariffa for plants provided various amendments: T1 = Control, T2 = NPK $60 \mathrm{~kg} \cdot \mathrm{ha}^{-1}, \mathrm{~T} 3=\mathrm{NPK} 120 \mathrm{~kg} \cdot \mathrm{ha}^{-1}, \mathrm{~T} 4=\mathrm{NPK} 180 \mathrm{~kg} \cdot \mathrm{ha}^{-1}$, T5 = poultry manure, $20 \mathrm{Mt} \cdot \mathrm{ha}^{-1}, \mathrm{~T} 6=$ poultry manure, $40 \mathrm{Mt}^{-\mathrm{ha}^{-1}}$. 


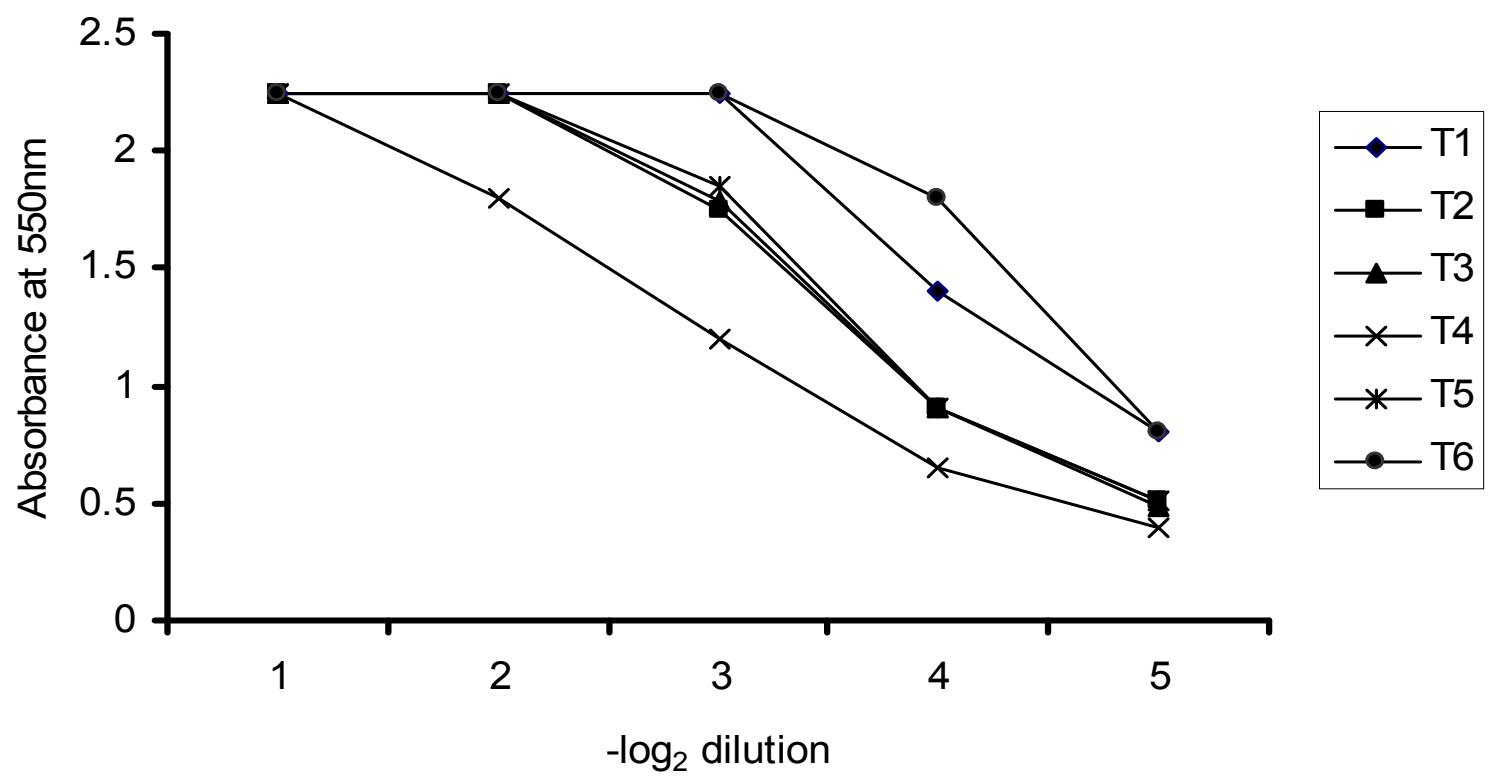

Fig 7: Optical density of water-diluted methanolic extracts of Calyces of Hibiscus sabdariffa L. plants grown under varying nutrient supplementation (T1= Control, T2 = NPK $60 \mathrm{kgha}^{-1}, \mathrm{T3}=\mathrm{NPK} 120 \mathrm{~kg} \mathrm{ha}^{-1}, \mathrm{~T}^{-1}=$ NPK $180 \mathrm{~kg} \mathrm{ha}^{-1}, \mathrm{T5}=$ poultry manure 20 ton ha ${ }^{-1}, \mathrm{~T} 6=$ poultry manure 40 ton ha ${ }^{-1}$ ).

Poultry manure has been shown to improve growth and productivity of Lactuca sativa (L.), Amaranthus spp, Brassica oleracea (Linn.), Lycopersicon esculentum (L.) and Solanum melongena (L.) (Zakaria and Vimala, 2002; Gibson and Waring, 1994). Aliyu et al. (2005) showed that when preceded by leguminous pasture the growth of Roselle was increased. This study has shown that supplementing soil with $20 \mathrm{Mt} \cdot \mathrm{ha}^{-1}$ of poultry manure increases biomass production of $H$. sabdariffa and enhances anthocyanin production. This is desirable, and the practice can be amended for commercial application.

\section{REFERENCES}

Ako, P.A.E., A.S. Adebanjo, A.L. Fabipe, and M.M. Ndamitso. 2003. Extractability of potassium from some organic manures in aqueous medium and the effect of $\mathrm{pH}$, time and concentration. J. App. Sci. Env. Mgt. 7: 51-56.

Aliyu, L., N.C. Kuchind, A.B. Lawal, and A.A. Muhammad. 2005. Evaluation of the agronomic potential, genetic variability and heritability in Roselle (Hibiscus sabdariffa L.) at Samaru, Nigeria. Crop Res. 30: 409413.

Ben-Porath, A. and D.M. Baker. 1990. Taproot restriction effects on growth, earliness and dry weight partitioning of Cotton. Crop Sci., 30: 809-814.
Gibson, T.A, and S.A. Waring. 1994. The soil fertility effects of Leguminous lay pastures on north-east Thailand: Effects on the growth of Roselle (Hibiscus sabdariffa cv. Altissima) and cassava (Manihot esculenta). Field Crops Res. 39: 119-127.

Gitelson, A.A., N.M. Merzlyak, and B.O. Chivkunova. 2001. Optical Properties and Nondestructive Estimation of Anthocyanin Content in Plant Leaves. Phytochem. Photobiol. 74: 38-45.

Pellizzer, V. 2004. Plants for the future. Edible, medical and useful plants for a healthier world. Charity No. 1057719. 4pp.

Schippers, R.R. 2000. African indigenous vegetables: An overview of cultivated species. Natural Resources Institute (NRI), University of Greenwich, Chatham, UK. $214 \mathrm{p}$

Williams C.N., J.O Uzo and W.T.H. Peregrine. 1991. Vegetable production in the tropics. International Tropical Agriculture Series. Longman Group, London, U.K.

Zakaria, A. and P. Vimala. 2002. Research and development of organic crop production in Malaysia. Expert group workshop on preparation of technical guidelines on organic cultivation of tropical and subtropical fruits, 22-26 July 2002, INTAN Bukit Kiara, Kuala Lumpur. 12pp. 